\title{
Are Indications and Findings of Upper Gastrointestinal System Endoscopy Changing in Children Over the Years?
}

\author{
Çocuklarda Yıllar İçinde Üst Gastrointestinal Sistem Endoskopi \\ Endikasyonları ve Bulguları Değişiyor Mu?
}

Melike Arslan* (0000-0002-0107-4699), Hilal Işık** (0000-0002-9383-2257), Necati Balamtekin* (0000-0001-8665-5611)

*University of Health Sciences Turkey, Gülhane Training and Research Hospital, Clinic of Pediatrics, Division of Pediatric Gastroenterology, Ankara, Turkey

**University of Health Sciences Turkey, Gülhane Training and Research Hospital, Department of Pediatrics, Ankara, Turkey

Keywords

Upper gastrointestinal system endoscopy, abdominal pain, epigastric pain, children

Anahtar kelimeler

Üst gastrointestinal sistem endoskopisi, karın ağrısı, epigastrik ağrı, çocuklar

Received/Geliş Tarihi : 25.07 .2021

Accepted/Kabul Tarihi : 03.09.2021

DOI:10.4274/jcp.2021.02359

Address for Correspondence/Yazışma Adresi: Melike Arslan MD, University of Health Sciences Turkey, Gülhane Training and Research Hospital, Clinic of Pediatrics, Division of Pediatric Gastroenterology, Ankara, Turkey

Phone: +90 5052878900

E-mail: melikearslan190@gmail.com

\begin{abstract}
Introduction: There are few studies of diagnostic endoscopy indications in children, despite the fact that it is a commonly performed procedure. The aim of the present study was to determine the relation between indications for upper gastrointestinal system (GIS) endoscopy and endoscopic and histopathologic findings in children in an effort to minimize unnecessary procedures.

Materials and Methods: The hospital files of 501 children and adolescents 1-18 years of age who underwent diagnostic upper GIS endoscopy examinations between June 2017 and June 2020 were evaluated retrospectively.

Results: The mean age of the 501 patients was $14.5 \pm 3.1$ years and $311(62.0 \%)$ were female. The most common indications for esophagogastroduodenoscopy (EGD) were epigastric pain $(38.7 \%)$ and abdominal pain $(29.3 \%)$ with abnormal endoscopic and histopathologic findings of $88.6 \%$ and $92.6 \%$, respectively. The co-detection rates of endoscopic and histologic abnormalities for the esophagus, stomach, and duodenum were $71.8 \%, 97.6 \%$, and $55.8 \%$, respectively. The most commonly detected endoscopic findings were antral gastritis $(66.4 \%)$, pangastritis $(18.0 \%)$, bile reflux $(12.6 \%)$, and duodenitis $(9.4 \%)$. The most commonly detected histopathologic findings were chronic gastritis $(45.3 \%)$, chronic Helicobacter pylori gastritis $(37.3 \%)$, edematous gastric mucosa $(5.4 \%)$, coeliac disease $(4.4 \%)$, and esophagitis $(4.4 \%)$. No complications were associated with the procedure itself or the required sedation.

Conclusion: Diagnostic endoscopy indications may vary between countries and centers. It has been established by many studies that the rates of negative endoscopic procedures and complications associated with EGD are high; therefore, the determination of accurate indications for this procedure is important.
\end{abstract}

$\ddot{\mathbf{O} z}$

Giriş: Sık uygulanan bir işlem olmasına rağmen çocuklarda tanısal endoskopi endikasyonları ile ilgili az sayıda çalışma bulunmaktadır. Bu çalışmanın amacı, çocuklarda üst gastrointestinal sistem (GIS) endoskopisi endikasyonları ile endoskopik ve histopatolojik bulgular arasındaki ilişkiyi belirlemek ve gereksiz işlemleri en aza indirgemektir.

Gereç ve Yöntem: Haziran 2017-Haziran 2020 tarihleri arasında tanısal üst GİS endoskopisi yapılan 1-18 yaş arası 501 çocuk ve adolesanın hastane dosyaları geriye dönük olarak değerlendirildi. 


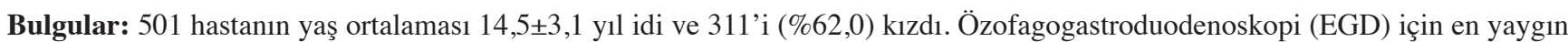
endikasyonlar epigastrik ağrı (\%38.7) ve karın ağrısı (\%29.3) olup anormal endoskopik ve histopatolojik bulgular sırasıyla \%88.6 ve \%92.6 idi. Özofagus, mide ve duodenum için endoskopik ve histolojik anormalliklerin birlikte tespit oranları sırasıyla \%71.8, $\% 97.6$ ve \%55.8 idi. En sık saptanan endoskopik bulgular antral gastrit (\%66.4), pangastrit (\%18.0), safra reflüsü (\%12.6) ve duodenit (\%9.4) idi. En sık saptanan histopatolojik bulgular kronik gastrit (\%45.3), kronik Helicobacter pylori gastriti (\%37.3), ödemli mide mukozası (\%5.4), çölyak hastalığı (\%4.4) ve özofajit (\%4.4) idi. İşlemin kendisi veya uygulanan sedasyon ile ilgili herhangi bir komplikasyon görülmedi.

Sonuç: Tanısal endoskopi endikasyonları ülkeler ve merkezler arasında farklılık gösterebilir. EGD ile ilişkili negatif endoskopik işlem ve komplikasyon oranlarının yüksek olduğu birçok çalışma ile tespit edilmiştir; bu nedenle, bu prosedür için doğru endikasyonların belirlenmesi önemlidir.

\section{Introduction}

Esophagogastroduodenoscopy (EGD) is an invasive intervention used commonly for the diagnosis and treatment of upper gastrointestinal system (GIS) diseases (1). In parallel to the development of pediatric gastroenterology, the use of EGD for the diagnosis and treatment of upper GIS diseases has become common in children (2). Despite the rapid increase in diagnostic and therapeutic procedures in children, normal (negative) endoscopic results are still surprisingly high $(1,3,4)$. As upper GIS endoscopy is an invasive procedure performed under general anesthesia or deep sedation, serious complications may occur in association with both anesthesia and the procedure itself. Therefore, it is very important that the decision to perform EGD be made based on judicious indications (3).

The aim of the present study was to determine the indications for EGD in children and evaluate the relationship between these indications and endoscopic and histopathologic findings in an effort to reduce the rate of unnecessary procedures.

\section{Materials and Methods}

A total of 501 patients, 1-18 years of age, who underwent upper GIS endoscopy at the Pediatric Gastroenterology Unit of the Gülhane Training and Research Hospital affiliated with the Health Sciences University between June 2017 and June 2020 were included in the study. Demographic characteristics, complaints, clinical findings, indications for diagnostic upper GIS endoscopy, and endoscopic and histopathologic findings were retrieved from the hospital data system and patient files. Indications for diagnostic EGD included the following: abdominal pain, epigastric pain, nausea/vomiting, dyspepsia, weight loss, failure to thrive, chronic diarrhea, unexplained anemia, hematemesis, dysphagia, positive coeliac serology, and miscellaneous causes (e.g. pica history and esophageal varices due to portal hypertension).

Under deep sedation induced by an anesthetist, upper GIS endoscopy was performed by the same pediatric gastroenterologist using an Olympus X260 scope (Olympus Optical Corporation, Japan).

Positive endoscopic findings included changes in mucosa (erythema, edema, erosion, nodularity, biliary residue, duodenal scalloping, fissures), superficial and deep ulcers, polyps, and varices. Biopsies were obtained as recommended by guidelines according to underlying indication and endoscopic findings (5). Biopsy samples to evaluate eosinophilic esophagitis, were taken from the proximal, middle, and distal esophagus, for Helicobacter pylori ( $H$ pylori) infection, two from the antrum and two from the corpus, for rapid urease test (Campylobacter-like organism (CLO) test) one from the antrum, and for coeliac disease one from the duodenal bulb and four from the second portion of duodenum. If there was no specific clinical suspicion, depending on indication or endoscopic findings, two duodenal biopsy samples (bulb+second portion of the duodenum), two gastric biopsy samples (antrum+corpus), and two esophageal biospy samples (proximal+distal esophagus) were obtained. Histopathological investigations were carried out by the same pathologist unaware of the clinical and endoscopic findings. Acute or chronic tissue inflammation, the presence of $H$ pylori and other infectious agents, polyps, intraepithelial lymphocytes, villus atrophy, crypt hyperplasia, and lymphangiectasia were considered positive histologic findings.

Biopsies were classified according to a histological score as follows: For the esophagus, mild inflammation=minor abnormalities (scanty 
intraepithelial polymorphs, or submucosal vascular dilatation, or basal epithelial cell thickening), and moderate-severe inflammation $=$ prominent intraepithelial polymorphs, ulcer slough present (6). For the stomach, superficial (mild) inflammation= limited to lamina propria in the foveolar region, moderate inflammation =extending to involve gastric glands, and deep (severe) inflammation= involving the full mucosal thickness (7). For the duodenum, mild inflammation $=$ increased cellularity of lamina propria, moderate inflammation =intraepithelial polymorphonuclear cells present $+/-$ increased cellularity of lamina propria, and severe inflammation= erosion or ulceration present (7).

The ethics committee of the study was taken with the date and decision number of 2020-386/24.09.2020.

Statistical evaluation of the data was performed using the Statistical Package for the Social Sciences (SPSS) for Windows, version 20.0. Descriptive statistics were expressed with numbers and percentages for categorical variables and with mean \pm standard deviationfor numerical variables. For the comparison of categorical variables with each other, chi-square or Fisher's exact test was used. A confidence interval of $95 \%$ was set and a p-value $<0.05$ was considered significant.

\section{Results}

Overall, 501 EGD procedures carried out within three years were evaluated. The mean age of the patients was $14.5 \pm 3.1$ years and $311(62.0 \%)$ were female.

The most common indications for diagnostic EGD were epigastric pain (38.7\%), abdominal pain (29.3\%), nausea/vomiting (28.7\%), dyspepsia (20.8\%), and positive coeliac serology (5.0\%) (Table 1).

Positive endoscopic and histopathologic results were found in $88.6 \%$ and $92.6 \%$ of the patients, respectively. Histopathologic findings were abnormal in 442 of 444 (99.5\%) patients with abnormal endoscopic findings and in 22 of 57 (38.6\%) patients whose endoscopic findings were normal $(\mathrm{p}<0.0001)$. The co-detection rates of endoscopic and histologic abnormalities for the esophagus, stomach, and duodenum were $71.8 \%$, $97.6 \%$, and $55.8 \%$, respectively. Abnormal endoscopic findings were detected in the stomach, duodenum and esophagus in $84.4 \%, 11.9 \%$, and $6.2 \%$ of the patients (patients may exhibit $>1$ finding). The most
Table 1. Demographic characteristics of the study population

\begin{tabular}{|c|c|c|}
\hline Sex & Number (n) & $\begin{array}{l}\text { Percentage } \\
(\%)\end{array}$ \\
\hline Female & 311 & 62.0 \\
\hline Male & 190 & 38.0 \\
\hline \multicolumn{3}{|l|}{ Age (years) } \\
\hline $1-6$ & 31 & 6.2 \\
\hline $7-14$ & 164 & 32.7 \\
\hline $15-18$ & 306 & 61.1 \\
\hline \multicolumn{3}{|l|}{ Indications for endoscopy } \\
\hline Epigastric pain & 194 & 38.7 \\
\hline Abdominal pain & 147 & 29.3 \\
\hline Nausea /vomiting & 144 & 28.7 \\
\hline Dyspepsia & 104 & 20.8 \\
\hline Positive coeliac serology & 25 & 5.0 \\
\hline Failure to thrive & 23 & 4.6 \\
\hline Weight loss & 14 & 2.8 \\
\hline Chronic diarrhea & 17 & 3.4 \\
\hline Hematemesis & 13 & 2.6 \\
\hline Unexplained anemia & 13 & 2.6 \\
\hline Dysphagia & 3 & 0.6 \\
\hline $\begin{array}{l}\text { Other indications (portal } \\
\text { hypertension, history of pica ) }\end{array}$ & 3 & 0.6 \\
\hline \multicolumn{3}{|l|}{ *The number of indications } \\
\hline 1 & 262 & 52.3 \\
\hline 2 & 223 & 44.5 \\
\hline 3 & 14 & 2.8 \\
\hline 4 & 2 & 0.4 \\
\hline Overall & 501 & 100 \\
\hline
\end{tabular}

common endoscopic findings were antral gastritis $(66.4 \%)$, pangastritis (18.0\%), bile reflux (12.6\%), and duodenitis $(9.4 \%)$, (Table 2$)$.

Abnormal histopathologic findings were detected in the stomach, duodenum, and esophagus in $88.4 \%, 9.6 \%$, and $4.6 \%$ of the patients, respectively (patients may have $>1$ finding). The most common histopathologic findings were chronic gastritis $(45.3 \%)$, chronic $H$ pylori gastritis $(37.3 \%)$, edematous gastric mucosa (5.4\%), coeliac disease (4.4\%), and esophagitis (4.4\%), (Table 3). No complications occurred in association with the procedure itself or the required sedation. In many patients, more than one indication was recorded. While no significant relationship was found between 


\begin{tabular}{lll}
\hline \multicolumn{2}{l}{ Table 2. Upper GI system endoscopy results } \\
\hline Endoscopy results & Number (n) & $\begin{array}{l}\text { Percentage } \\
(\%)\end{array}$ \\
\hline Normal & 57 & 11.4 \\
Esophagitis & 27 & 5.4 \\
Lower esophageal sphincter & 4 & 0.8 \\
insufficiency & 5 & 1.0 \\
Esophageal ulcer & 2 & 0.4 \\
Esophageal varices, portal & & 66.4 \\
gastropathy & 333 & 5.4 \\
Antral gastritis & 27 & 18.0 \\
Antral ulcer & 90 & 0.4 \\
Pangastritis & 2 & 1.0 \\
Gastric polyp & 5 & 12.6 \\
Pyloric dysfunction & 63 & 1.0 \\
Bile reflux & 5 & 1.2 \\
Bulbitis & 6 & 9.4 \\
Bulbar ulcer & 47 & 5.2 \\
Duodenitis & 26 & $\mathbf{1 0 0}$ \\
Endoscopic findings suggestive \\
of coeliac (duodenal scalloping)
\end{tabular}

*29.1\% of patients had more than one abnormal finding

the number of indications and the rate of endoscopic abnormalities $(\mathrm{p}=0.13)$, a significant relationship was found between the number of indications and histopathologic abnormalities $(\mathrm{p}=0.02)$. No significant relationship was found between gender and endoscopic and histopathologic abnormalities $(\mathrm{p}=0.51, \mathrm{p}=0.70)$; however, there was a relationship between age groups and the rate of duodenitis $(\mathrm{p}=0.01)$. In detailed analyses, a significant difference was found between the 1 to 6 year group and the $>15$ year group. While the probability of duodenitis was $14.3 \%$ in the younger group, it dropped to $1.7 \%$ in those $>15$ years of age. In addition, age was found to also affect the rate of edematous mucosa $(\mathrm{p}<0.001)$. A significant difference was found between the 1 to 6 year group (31.8\%) and the $>15$ year group (3.2\%). No significant relationship was found between endoscopic and histopathologic abnormalities and the most common indications of epigastric pain $(\mathrm{p}=0.63, \mathrm{p}=0.80)$, abdominal pain $(\mathrm{p}=0.16, \mathrm{p}=0.51)$, and nausea/vomiting $(\mathrm{p}=0.08$, $\mathrm{p}=0.06)$.

\section{Discussion}

GIS endoscopy has been used since the 1970s in children and the incidence of diseases requiring its use for diagnosis has risen with its increased usage. Franciosi et al. (2) reported that there was a 12-fold increase in the number of EGDs per 100,000 children between 1985 and 2005 in the Philadelphia, PA region of the United States and that this increase was due to the increase in the number of diagnostic procedures, rather than the increase in the incidence of disease (2).

There are a limited number of studies investigating the indications for diagnostic endoscopy in children. Reports indicate that until the mid-1990s, the most common indication for diagnostic endoscopy was GIS bleeding, while in subsequent years, epigastric pain and abdominal pain became more preponderant (2). Actually, at present, the most common cause for consultation with a pediatric gastroenterologist by a primary physician is abdominal pain (1). Recent investigations have revealed that abdominal pain is also the most common indication in children for diagnostic upper GI endoscopy $(1,8)$. This change may be associated with the definition of $H$ pylori, the causative agent for peptic ulcers, and development of effective treatment protocols, including widespread clinical use of strong acid-suppressing drugs, and developments in the management of diseases producing susceptibility to GI bleeding such as variceal bleeding due to portal hypertension (2). In the present study, the most common indications for EGD were epigastric pain $(38.7 \%)$ and abdominal pain $(29.3 \%)$. Our results are consistent with the literature and strongly support the idea that pediatric EGD indications have changed within the last 20 years, with abdominal pain being the predominant indication.

Performing endoscopy, which is an invasive procedure, for proper indications is the best approach for preventing probable complications. Studies demonstrated that there are no positive endoscopic findings in a sizable proportion of EGD procedures performed in children (4). Noble et al. (4) reported the rate of endoscopic and histological abnormalities to be $55 \%$ in 346 EGD procedures conducted in 2008. In another study, O'Loughlin et al. detected no abnormal endoscopic findings in $48 \%$ of 1055 diagnostic EGD procedure (9). In the present study, abnormal endoscopic findings were found in $88.6 \%$ of patients, indicating that normal endoscopy results (negative 
Table 3. Upper GI system endoscopic and histopathologic findings

\begin{tabular}{|c|c|c|c|}
\hline Endoscopic findings & & Number (n) & Percentage $(\%)$ \\
\hline \multirow[t]{3}{*}{ Esophagus } & Erythema, edema, erosion & 27 & 5.4 \\
\hline & Ulcer & 5 & 1.0 \\
\hline & Lower esophageal sphincter insufficiency & 4 & 0.8 \\
\hline \multirow[t]{5}{*}{ Stomach } & Erythema, erosion, edema, nodularity & 423 & 84.4 \\
\hline & Ulcer & 27 & 5.4 \\
\hline & Gastric polyp & 2 & 0.4 \\
\hline & Biliary residue & 63 & 12.6 \\
\hline & Pyloric dysfunction & 5 & 1.0 \\
\hline \multirow[t]{4}{*}{ Duodenum } & Erythema, erosion, edema & 54 & 10.8 \\
\hline & Ulcer & 6 & 1.2 \\
\hline & Scalloping & 20 & 4.0 \\
\hline & Fissures & 6 & 1.2 \\
\hline Portal hypertension & Varices, gastropathy & 2 & 0.4 \\
\hline \multicolumn{2}{|l|}{ Histopathologic findings } & Number (n) & Percentage $(\%)$ \\
\hline \multirow[t]{5}{*}{ Esophagus } & Mild inflammation & 6 & 1.2 \\
\hline & Moderate- severe inflammation & 15 & 3.0 \\
\hline & Edematous mucosa & 1 & 0.2 \\
\hline & Candida esophagitis & 1 & 0.2 \\
\hline & Eosinophilic esophagitis & 1 & 0.2 \\
\hline \multirow[t]{5}{*}{ Stomach } & Mild inflammation & 263 & 52.4 \\
\hline & Moderate-severe inflammation & 151 & 30.1 \\
\hline & Edematous mucosa & 27 & 5.4 \\
\hline & Helicobacter pylori infection & 187 & 37.3 \\
\hline & Hyperplastic polyp & 2 & 0.4 \\
\hline \multirow[t]{7}{*}{ Duodenum } & Mild inflammation & 4 & 0.8 \\
\hline & Moderate-severe inflammation & 6 & 1.2 \\
\hline & Edematous mucosa & 4 & 0.8 \\
\hline & Intraepithelial lymphocytes & 32 & 6.4 \\
\hline & Villus atrophy & 22 & 4.4 \\
\hline & Crypt hyperplasia & 22 & 4.4 \\
\hline & Lymphangiectasia & 2 & 0.4 \\
\hline
\end{tabular}

results) were at lower rates compared to the literature. This may be attributed to the development of devices offering higher quality endoscopic imaging and evaluation opportunities and the increasing awareness of health professionals to the issue in parallel to the advances in technology.

In upper GIS endoscopy procedures, the correlation between endoscopic abnormalities and histologic abnormalities is another important issue. Sheiko et al. reported that in 1000 EGD procedures they found endoscopic abnormalities and histologic abnomalities in $34.7 \%$ and $40.4 \%$, respectively (3). In another study, it was stated that in conditions in which a biopsy is obtained only from mucosal areas appearing pathological, histopathological abnormalities were missed at the rate of $48.5 \%$ by EGD and that codetection rates between endoscopic and histologic abnormalities were $82.6 \%, 73.2 \%$, and $89.3 \%$ for 
esophagus, stomach, and duodenum, respectively (10). Therefore, recent European Society of Gastrointestinal Endoscopy (ESGE)/ European Society for Paediatric Gastroenterology Hepatology and Nutrition (ESPGHAN) guidelines have recommended that, even if the mucosa has a normal appearance, biopsies should be obtained from the esophagus, stomach, and duodenum (5). In the present study, histopathologic findings were abnormal in 22 of 57 patients whose endoscopic findings were normal. Co-detection rates between endoscopic and histopathologic abnormalities were $71.8 \%, 97.6 \%$, and $55.8 \%$, for the esophagus, stomach, and duodenum, respectively.

The leading cause of gastritis in children is $H$ pylori infection, which also accounts for the majority of duodenal ulcers $(11,12)$. H pylori prevalence varies largely with the geographical region, with a prevalence in Turkey of $82.5 \%$ (13). Although there are no specific symptoms of $H$ pylori infection in children, recurrent abdominal pain is the main sign suggesting $H$ pylori infections to clinicians and is a common indication for EGD (12). In the present study, among patients undergoing EGD, chronic gastritis was identified in $45.3 \%$ and $H$ pylori gastritis in $37.3 \%$. According to endoscopic investigation, $66.4 \%$ of patients had antral gastritis, $18.0 \%$ pangastritis, $5.4 \%$ an antral ulcer, and $1.2 \%$ a bulbar ulcer. Antral gastritis was founded in $76 \%$ of the patients with $H$ pylori gastritis.

The diagnosis of functional dyspepsia is made in the presence of postprandial fullness, early satiation, epigastric pain, and burning for at least two months according to Rome IV criteria (14). Robin et al. reported the prevalence of functional dyspepsia to be $7.6 \%$ in a recent study (15). In a study carried out on children with dyspepsia symptoms, EGD was performed in $44 \%$ of the cases 39 days after the first examination and $62 \%$ were found to be normal (16). In the present study, $20.8 \%$ of the patients had complaints of dyspepsia and $37.8 \%$ epigastric pain. EGD yielded normal results in $26.3 \%$ of these patients with functional dyspepsia. We believe that the lower rate of normal EGD results in our study compared to those reported in the literature maybe due to the fact that our patient group had chronic symptoms refractory to treatment.

It was reported that reflux and heartburn symptoms occur weekly in $2 \%$ of children 3-9 years of age, and $5 \%-8 \%$ of those between the ages of $10-17$ years.
In reflux esophagitis, sensitivity, specificity and the positive predictive value of EGD vary between $29 \%$ $86 \%, 21 \%-83 \%$, and $80 \%-82 \%$, respectively (16). In the study by Noble et al. (4) esophagitis was detected endoscopically at the rate of $18 \%$, esophageal ulcer at $1 \%$, lower esophageal sphincter insufficiency at $3 \%$, and histologicaly esophagitis was found at the rate of $9 \%$ (4). In the study by O'Loughlin et al. (9) esophagitis was found at the rate of $16 \%$ in 1172 EGD procedures. In the present study, endoscopic findings were as follows: esophagitis $5.4 \%$, ulcer $1 \%$ and lower sphincter insufficiency $0.8 \%$. As to histopathologic findings, reflux esophagitis was found at the rate of $4.2 \%$ and eosinophilic and candida esophagitis at $0.2 \%$.

ESPGHAN guidelines recommend that in children with anti-tTG IgA positivity at low titers $(<10 \mathrm{x}$ upper limit of normal), at least five biopsy samples should be obtained (one from the dudenal bulb, and four from the second portion of the duodenum) to decrease falsenegative results (17). In the study of Sheiko et al. (3) coeliac disease was detected histologicaly in $94.2 \%$ of patients with positive coeliac autoantibodies, while in the study by Aydin et al. (8) the corresponding rate was $78 \%$. In the present study, 25 patients with positive coeliac antibodies detected serologicaly underwent EGD investigation and 22 (88\%) were diagnosed with coeliac disease following histopathologic examination.

As far as we know, there is no study in the literature investigating the relationship between age groups and duodenitis and edematous mucosa. In the present study, an effect of age on duodenitis and edematous mucosa rates found by endoscopy was observed $(p=0.01, p<0.001)$. In a detailed analysis, a significant difference was found between those 1-6 years of age and those $>15$ years of age. While in the younger group the probability of duodenitis was $14.3 \%$, and that of edematous mucosa $31.8 \%$, in those $>15$ years of age, the corresponding figures were found to be $1.7 \%$ and $3.2 \%$, respectively. The absence of made other studies and results on this subject is one of the limitations of our study.

\section{Conclusion}

In conclusion, genetic background, nutritional habits, and socioeconomic status of communities are the most important factors determining the prevalence and type of GIS diseases. Thus, diagnostic endoscopy 
indications may differ from country to country. As a high rate of negative endoscopic procedures and complications due to EGD have been reported in many published studies, determining accurate indications for the procedure is important. Diagnosic EGD indications should be determined after a thorough evaluation of abdominal pain, dyspepsia, reflux complaints, positive coeliac serology and failure to thrive, which are considered the most common indications for diagnostic endoscopy. The correct determination of indications for diagnostic endoscopy will help to increase the correlation of indications with endoscopic findings and histopathologic results.

\section{Acknowledgement}

We are grateful for Prof. Dr. Hasan Özen valuable contribution to our study.

\section{Ethics}

Ethics Committee Approval: Local ethics committee approval was obtained from Gülhane Training and Research Hospital by decision number 2020/386 on Sep 24, 2020.

Conflict of Interest: No conflict of interest was declared by the authors.

Financial Disclosure: The authors declare that they have no conflicts ofinterest. Informed consent was obtained from all individual participants included in the study.

\section{References}

1. Alabd Alrazzak B, Husien T, Preston DL, Elitsur Y. Upper endoscopy in children: do symptoms predict positive findings? Clin Pediatr (Phila) 2014;53(5):474-8.

2. Franciosi JP, Fiorino K, Ruchelli E, Shults J, Spergel J, Liacouras CA, et al. Changing indications for upper endoscopy in children during a 20-year period. J Pediatr Gastroenterol Nutr 2010;51:443-7.

3. Sheiko MA, Feinstein JA, Capocelli KE, Kramer RE. Diagnostic yield of EGD in children: a retrospective single-center study of 1000 cases. Gastrointest Endosc 2013;78:47-54.e1.

4. Noble AJ, Drouin E, Tamblyn R. Design of predictive models for positive outcomes of upper and lower gastrointestinal endoscopies in children and adolescents. J Pediatr Gastroenterol Nutr. 2008; 46: 409-13.

5. Thomson M, Tringali A, Dumonceau JM, Tavares M, Tabbers MM, Furlano R, et al. Pediatric Gastrointestinal Endoscopy: European Society of Gastrointestinal Endoscopy (ESGE) and European Society for Paediatric Gastroenterology Hepatology and Nutrition (ESPGHAN) Guideline Executive Summary. Endoscopy 2017;49(1):83-91.

6. Bate CM, Keeling PW, O'Morain C, Wilkinson SP, Foster DN, Mountford RA, et al. Comparison of omeprazole and cimetidine in reflux oesophagitis: symptomatic, endoscopic, and histological evaluations. Gut 1990;31(9):968-72.

7. Black D.D, Haggitt R.C, Whitington P.F. Gastroduodenal Endoscopic-Histologic Correlation in Pediatric Patients. Journal of Pediatric Gastroenterology and Nutrition 1988;7(3):353-8.

8. Aydin M, Niggeschmidt J, Ballauff A, Wirth S, Hensel KO, et al. Common Indications and The Diagnostic Yield of Esophagogastroduodenoscopy in Children with Gastrointestinal Distress. Klin Padiatr 2019;231(1):21-7.

9. O'Loughlin E.W, Dutt S, Kamath R , Gaskin K, Dorney S, et al. Prospective peer-review audit of paediatric upper gastrointestinal endoscopy. Journal of Paediatrics and Child Health 2007;43(78):551-4.

10. Sheiko M.A, Feinstein J.A, Capocelli K.E, Kremer RE. The concordance of endoscopic and histologic findings of 1000 pediatric EGDs. Gastrointest Endosc 2015;81:1385-91.

11. Glickman JN, Antonioli DA. Gastritis. Gastrointest Endosc Clin N Am 2001;11(4):717-40.

12. Marco M, Federica G, Stefano K, Bizzarri B, Iuliano S, Minelli $\mathrm{R}$ et al. How and when investigating and treating Helicobacter pylori infection in children. Acta Biomed 2018;89(8):65-71.

13. Ozaydin N, Turkyilmaz SA, Cali S. Prevalence and risk factors of Helicobacter pylori in Turkey: a nationally-representative, cross-sectional, screening with the ${ }^{13} \mathrm{C}$-Urea breath test. BMC Public Health. 2013;13:1215.

14. Browne P.D, Nagelkerke S.C.J, van Etten-Jamaludin F.S et al. Pharmacological treatments for functional nausea and functional dyspepsia in children: a systematic review. Expert Rev Clin Pharmacol 2018; 11(12):1195-208.

15. Robin SG, Keller C, Zwiener R, Hyman PE, Nurko S, Saps M et al. Prevalence of Pediatric Functional Gastrointestinal Disorders Utilizing the Rome IV Criteria. The Journal of pediatrics 2018;195:134-39.

16. Adamiak T, Plati K.F. Pediatric Esophageal Disorders: Diagnosis and Treatment of Reflux and Eosinophilic Esophagitis. Pediatr Rev 2018;39(8):392-402.

17. Husby S, Koletzko S, Korponay-Szabó I, Kurppa K, Mearin ML, Ribes-Koninckx $\mathrm{C}$ et al. European Society Paediatric Gastroenterology, Hepatology and Nutrition Guidelines for Diagnosing Coeliac Disease 2020. Journal of Pediatric Gastroenterology and Nutrition 2020;70(1):141-56. 